\title{
The Effect of Capital Expenditures and General Allocation Funds on Local Financial Independence Through Local Revenue as an Intervening Variable in Districts and Cities in North Maluku Province
}

\author{
Harry Setiadi Utomo, Rusman Soleman, Hartaty Hadady \\ Management Study Program, Local Financial Management Concentration, Khairun University, Ternate
}

\begin{abstract}
This study aims to examine the effect of capital expenditure and general allocation funds on local financial independence, either directly or mediated by local revenue. The population is the APBD Realization Report from website of Director General of Local Government Matching Grant. The samples are the document of APBD Realization Report for Regency / City Governments in North Maluku Province for 2015-2019. Data are collected from 2015-2019 District and City Government APBD Realization Reports in North Maluku Province, BPK RI Audit Results Reports and website http://www.djpk.kemenkeu.go.id/ . The collected data is analyzed by multiple regression analysis and path analysis. The analysis found four findings. First, the General Allocation Fund partially has no effect on Local Financial Independence. Second, Capital expenditure partially does not affect on local financial independence. Third, the General Allocation Fund indirectly has a significant effect on Local Financial Independence through Local Revenue. Forth, Capital expenditure indirectly has a significant effect on Local Financial Independence through Local Revenue.
\end{abstract}

DOI: $10.7176 / \mathrm{DCS} / 11-4-03$

Publication date: April $30^{\text {th }} 2021$

\section{INTRODUCTION}

The paradigm of local financial management has changed since the implementation of local autonomy in 2001 . Law no. 32 year 2004 and Law No. 33 year 2004 are the main basis for implementation of local autonomy. These essentially provide greater opportunities for regions to optimize the potential. This law is a form of broader powers sharing from central government to local governments.

Local autonomy era delegates authority from central government to local governments. Local governments are given the authority to do local tasks in the context of fiscal decentralization implementation, which is financed by Local Expenditure and Revenue Budget (APBD). APBD is a reflection of programs that will be implemented by local governments during a certain period. The APBD is used as a reference for local governments to implement the government system. Halim (2007) stated that ability of local governments to manage local finances was stated in Local Expenditure and Revenue Budget (APBD), which directly or indirectly reflects the ability of local governments to finance the implementation of government tasks, development and community social services.

One manifestation of local autonomy implementation is decentralization. Law no. 32 year 2004 defined decentralization as the devolution of government power from central government to autonomous regions to set up and administer governmental affairs in Unitary State of Indonesia Republic.

The handover of local authority was also followed by handover of financing sources from Central Government. The regions can implement all governmental affairs themselves because the sources of financing have been submitted to local government. If this mechanism has been realized, aspirations for local independence can be realized. The sources of financing submitted to regions will later be manifested through a strong Local Revenue (PAD) structure. This PAD is a source of financing that is really extracted from the region to reflect the real conditions of the region. Strong PAD structure shows the region has a strong financing capacity to realize local financial independence (Muliana, 2008).

Regions with low fiscal capacity tend to have strong fiscal pressure (Adi, 2006). This low capacity indicates a low level of local financial independence. Asnidar and Hardi (2018) conducted a study on the effect of capital expenditure on financial performance of local government of Langsa City. The results showed that capital expenditure had a significant effect on financial performance. Erlanda (2016) also found that capital expenditures and government capital participation, have a positive effect on level of local financial independence. On other hand, the theory of Peacok and Wiseman which is based on view that government always tries to increase expenditure while the people do not like to pay bigger taxes to finance the higher government expenditure.

Kadafi, Dhanny, and Dewi Wahyuni (2018) found that capital expenditure did not have a significant effect on level of local financial independence in all districts / cities in province of East Kalimantan. Fajri (2015) also found that capital expenditure did not have a significant effect in increasing the economic growth of provinces in 
Sumatra. Furthermore, Brodjonegoro and Vasque (2002) found that DAU has no influence on the efforts to increase local taxes in districts or cities in Indonesia.

The fiscal gaps between regions require the central government to transfers grant to local governments. This condition does not provide good guidance for government on function of transfer fund flow itself (Rizky and Suryo, 2009). Saruc and Sagbas (2008) found that transfer funds to local governments ( intergovernmental transfers ) can be a substitute or can be a stimulus for local expenditure to create economic growth.

The progress of a region can be seen with good economic growth. One factor to affect economic growth is the local government investment. The amount of capital expenditure is a reflection of infrastructure and facilities development that should have a positive influence on economic activities of community which in turn will increase the local independence through larger local revenue.

Local revenue (PAD) and capital expenditure affect the local financial performance. Puspitasari et al. (2015) found that capital expenditure can have a direct effect on performance, and also indirect effect through capital expenditure to local revenue as an intervening variable and then to financial performance growth. In addition, Nugroho (2012) found that capital expenditure has no effect on financial performance of local governments. Capital expenditure has a significant positive effect on financial performance growth through local revenue (PAD).The mixed results of research on effect of general allocation funds and capital expenditures on local financial independence motivated the authors to re-examine these variables in North Maluku Province.

\section{THEORETICAL BASIS}

Local Expenditure and Revenue Budget (APBD )

Law Number 32 year 2004 on Local Government defined APBD as a local government financial operational plan. On one hand, it describes the estimated expenditure to finance local activities and projects in a particular fiscal year and on other hand it describes the estimated revenue and sources of local revenue to cover the expenses.

Based on Law Number 32 year 2004 on Local Government, APBD structure is a unit consisting of local revenue, local expenditure and financing. Local income is all local rights as an addition to net asset value in one fiscal year. Local expenditures are all local obligations that are recognized as a reduction in net assets value within a one year fiscal. Financing is any revenue that needs to be paid back and / or expenditure that will be received back, both in relevant fiscal year and in subsequent fiscal years. Local financing consists of financing revenue and financing expenditures.

\section{Local Financial Independence}

Local financial independence (fiscal autonomy) shows the ability of local governments to self-finance the government activities. The independency ratio is calculated by comparing the local revenue and central or provincial government assistance and loans.

The relations pattern between the central and local governments as well as the level of independence and local financial capacity can be shown in Effectiveness and Efficiency Ratio of Local revenue. The effectiveness ratio describes the government's ability to realize planned local revenue compared to target set based on real potential of region.

\section{General Allocation Fund}

The General Allocation Fund is local revenue that comes from balance fund group. Article 1 Paragraph 21 in Law no. 33/2004 explained that General Allocation Fund (DAU) is a fund sourced from APBN allocated to create equitable distribution of financial capacity among regions to finance local needs in context of decentralization implementation. DAU is given by central government to finance the shortcomings of local governments in utilizing their local revenue. DAU is a "Block Grant" submitted to regions in accordance with local priorities and needs to improve the community services in context of local autonomy implementation.

This definition shows that DAU become a tool to overcome the fiscal imbalances between regions and also a source of local financing. This means that provision of DAU priority is regions with low fiscal capacity. Regions with high fiscal capacity will receive a smaller amount of DAU. It should reduce the fiscal disparities between regions in the era of autonomy (Adi, 2006). The basic concept of DAU formulation as mandated in Law No.25 of 1999 is the elaboration of governmental transfer theory based on concept of a fiscal gap . The fiscal gap is the negative difference between fiscal needs and fiscal capacity.

Kuncoro (2004) stated that DAU transfers can be classified as general assistance. However, due to financial situation and conditions, local governments have been forced to allocate DAU to finance salaries.

\section{Capital Expenditure}

Local expenditures are grouped into direct and indirect expenditures. Direct expenditure consists of personnel expenditure, goods and services expenditures and capital expenditures. Permendagri No. 13 year 2006 Article 
53 stated that Capital expenditures were used for purchasing / procuring or constructing tangible fixed assets that have a useful value of more than 12 months to be used in government activities, such as land, equipment and machinery, buildings, roads, irrigation and other networks.

Wagner's law, namely the law of government expenditure, states that higher economic growth in a region will increases the government capital expenditure. The Keynesian opinion also states that increase in government capital expenditure should increase the demand for public consumption which will be balanced by higher production and economic growth increase.

The construction of facilities and infrastructure for benefit of public services is funded from allocation of capital expenditures. The economic growth of a region motivates local government to increase capital expenditure for maintenance and infrastructure with aim to achieve better economic growth.

Mardiasmo (2009) stated that "Capital Expenditures have benefits above one fiscal year and will increase the routine budget for operational and maintenance costs". It can be concluded that capital expenditure comes from a budget in local government used to get fixed assets or other assets that can provide benefits for more than one accounting period and used by local governments to serve public.

\section{Research Framework}

The research framework at figure 1 is based on above theoretical basis and different research results related to effect capital expenditure and general allocation funds on local financial independence.

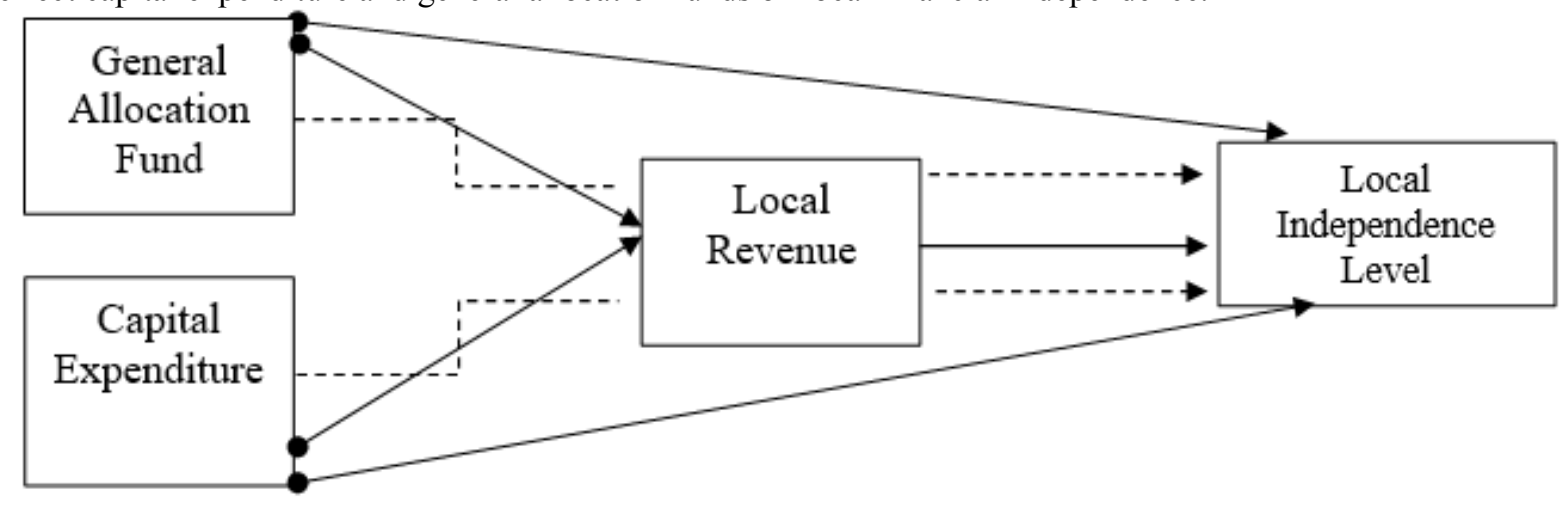

\section{Description:

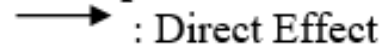 \\ $-\cdots$ : Indirect Effect}

Figure 1. Research Framework

\section{Hypothesis Development}

Sidik (2004) stated that larger DAU was distributed to regions with relatively small financial capacity. In other words, central government allocates a relatively large DAU for less independent region. This is because the local PAD is small so that central government needs to allocate funds to these regions.

Muliana (2009) explains that DAU has a significant negative effect on level of local financial independence in Districts / Cities Governments in North Sumatra Province. Based on explanation above, researchers suspect that General Allocation Fund (DAU) affects the level of local financial independence. Large DAU allocation regions become indication that the region is less independent because the region still relies on central government as the main revenue. Therefore, the hypothesis is stated below

H1: General Allocation Funds have a significant effect on local financial independence in districts / cities of North Maluku Province .

Public Accounting Standard Guide (PSAP) Number 2 explained that Capital Expenditures are budget for acquisition of fixed assets and other assets to provide benefits for more than one accounting period. Capital expenditures have specific characteristics to indicate various considerations in their allocation. Acquisition of fixed assets also has consequences on future operating and maintenance expenses (Bati, 2009).

Lusiana (2013) explained that allocation of capital expenditure has a positive but insignificant effect on level of financial independence of Regency / City Governments in Java island. Holtz-Eakin et al. in Rizky and Suryo (2009) showed a very close relationship between transfers from central government and capital expenditures. Prakoso's findings in Rizky and Suryo (2009) showed that the amount of capital expenditure is influenced by general allocation funds received from central government. This provides a strong indication that behavior of local expenditures, especially capital expenditures, will be strongly influenced by this source of revenue. Therefore, the hypothesis is stated below. 
H2 : Capital Expenditures have a significant effect on level of local financial independence in districts / cities of North Maluku Province.

Local autonomy gives regions the authority to explore financial sources in their respective regions to finance their own local expenditures. Prakoso findings in Rizky and Suryo (2009) showed the opposite indication that amount of capital expenditure is influenced by general allocation funds received from central government, local independence does not get better, in fact what happens is the opposite, namely the dependence of local governments on central government transfers is higher. This provides a strong indication that behavior of local expenditures, especially capital expenditures, will be strongly influenced by this source of revenue.

Local autonomy gives regions authority to explore financial sources to finance their own local expenditures, which consist of (routine) operational and capital expenditures. The financing is obtained from PAD. Therefore, it is necessary to examine the effectiveness of region's original revenue supported by financial balancing fund between the central government and local equal to Province and Regency / City, which includes general allocation funds and special allocation funds. The more effective the local government in managing local revenue (PAD), it will increase the amount of local revenue. Large PAD should reduce the amount of DAU given by central government. It makes the region become independent. This independence level is indicated by contribution of PAD to finance local expenditures. Therefore, the hypothesis is stated below.

H3: General Allocation Funds have a significant effect on local financial independence mediated by local revenue in districts / cities of North Maluku province.

H4: Capital Expenditures have a significant effect on local financial independence in districts / cities in North Maluku province mediated by local revenue.

\section{RESEARCH METHODOLOGY}

This is a quantitative research with ex post facto approach to find causes that allow changes in behavior, symptoms or phenomena caused by an event, behavior or things to changes independent variables as a whole (Widarto, 2013). The population is the APBD Realization Report from website of Director General of Local Government Financial Balance. APBD realization report provides data on amount of realization of Capital Expenditure Budget and General Allocation Fund (DAU). The samples are the document of APBD Realization Report for Regency / City Governments in North Maluku Province 2015-2019. Samples were selected by purposive sampling by researching the literature and searching for information via the internet The research was conducted by collecting secondary data taken from 2015-2019 District and City Government APBD Realization Reports in North Maluku Province, BPK RI Audit Results Reports and from website http://www.djpk.kemenkeu.go.id/ . The method used to test the effect of independent variable on dependent variable is the Multiple Linear Regression method

\section{RESULTS AND DISCUSSION}

Description of research data

The General Allocation Fund has an average of 1688.91 with a standard deviation of 1284.88 while the minimum value is 65.09 for East Halmahera Regency in 2015 and maximum value is 51.25\% in Morotai Island Regency in 2015. Capital Expenditure variable has an average of $30.75 \%$ with a standard deviation of $9.05 \%$ while the minimum value is $17.40 \%$, namely Tidore City in 2017 and a maximum value is $60.97 \%$ for Taliabu Island Regency in 2015.

Local revenue has an average of $8,585,968,915.26$ with a standard deviation of $115,331,526,497.05$ while the minimum value is 7,134,684,793.26, namely Taliabu Island Regency in 2019 and maximum value is $593,120,908,268$, namely East Halmahera Regency in 2015. Descriptive results of Local Financial Independence shows an average value of $7.78 \%$ with a standard deviation of $12.24 \%$, the minimum value was $0.18 \%$, for Morotai Island Regency in 2017 and maximum value of 89.12\%, for East Halmahera Regency in 2015.

\section{Hypothesis testing}

The direct effect consists of variable General Allocation Fund $\left(\mathrm{X}_{1}\right)$, Capital Expenditure $\left(\mathrm{X}_{2}\right)$ on Local revenue $(Z)$. This section will analyze the partial test ( $t$ test), simultaneous test ( $F$ test), and coefficient of determination. Tables 1 and Table 2 show the results of direct effect analysis using multiple regressions. 
Table 1 . Regression of X1, X2 to Z

\begin{tabular}{|c|c|c|c|c|c|}
\hline Variable & $\begin{array}{c}\text { Unstandardized } \\
(\mathbf{B})\end{array}$ & $\begin{array}{c}\text { Standardized } \\
\text { (Beta) }\end{array}$ & $\begin{array}{c}\text { Std. } \\
\text { Error }\end{array}$ & tcount & Sig. \\
\hline $\mathrm{X}_{1}$ & -0.005 & -0.537 & 0.001 & -4.362 & 0.000 \\
\hline $\mathrm{X}_{2}$ & -0.052 & -0.041 & 0.157 & -0.332 & 0.741 \\
\hline Constant & 17.797 & & & \\
\hline Fcount; Sig & $11.394 ; 0.000$ & & \\
\hline Rsquare & 0.305 &
\end{tabular}

Table 2 . Regression for X1, X2, Z on Y

\begin{tabular}{|c|c|c|c|c|c|}
\hline Variable & $\begin{array}{c}\text { Unstandardized } \\
\text { (B) }\end{array}$ & $\begin{array}{c}\text { Standardized } \\
\text { (Beta) }\end{array}$ & $\begin{array}{l}\text { Std. } \\
\text { Error }\end{array}$ & $\mathbf{t}_{\text {count }}$ & Sig. \\
\hline $\mathrm{X}_{1}$ & 0.000 & -0.020 & 0.001 & -0.202 & 0840 \\
\hline $\mathrm{X}_{2}$ & 0.058 & 0.043 & 0.113 & 0.508 & 0.614 \\
\hline $\mathrm{Z}$ & 0.876 & 0.825 & 0.100 & 8753 & 0.000 \\
\hline Constant & \multicolumn{5}{|l|}{-0.727} \\
\hline Fcount; Sig & \multicolumn{5}{|l|}{$36.938 ; 0.000$} \\
\hline Rsquare & \multicolumn{5}{|l|}{0.685} \\
\hline \multicolumn{6}{|c|}{$Y=a+b_{1} X 1+b_{2} X 2+b_{2} Z+e$} \\
\hline
\end{tabular}

\section{Simultaneous Test (F Test)}

The simultaneous test aims to determine the simultaneous effect of independent variables on dependent variable. This test is shown in ANOVA output table. The $F_{\text {count }}$ value is 377.020 and significance is 0.000 , so that calculated $\mathrm{F}$ value is greater than the $\mathrm{F}$ table and significance is less than 0.05 , it can be concluded that there is a simultaneous effect of variables of General Allocation Funds, Capital Expenditures and Local revenue on Local Financial Independence. This also means that regression model $\mathbf{Y}=\mathbf{- 0 . 7 2 7}+\mathbf{0 . 0 0 0 X} \mathbf{X}_{\mathbf{1}}+\mathbf{0 . 0 5 8 X} \mathbf{2}_{\mathbf{2}}+\mathbf{0 . 8 7 6 Z}+$ $\mathbf{0 . 2 6 3}$ is suitable to use.

\section{Hypothesis testing \\ Hypothesis H1}

The General Allocation Fund variable has a t value of -0.202 and a significance of $0.840>0$. 05 . It means that partially General Allocation Fund does not have significant effect on Independence of Finance Region. Therefore, hypothesis $\mathrm{H} 1$ is rejected.

Sidik (2004) stated that DAU distribution to regions with relatively large capacities will be smaller. In other words, central government allocates a relatively large DAU to less independent region. The study results are inconsistent with Muliana (2009) that DAU has a significant negative effect on local financial independence in Regency / City Government in North Sumatra Province. Based on explanation above, researchers suspect that General Allocation Fund (DAU) affects the level of local financial independence. Relatively large DAU allocation by central government to regions becomes indication that the region is less independent. The regions still uses the funds from central government as the main revenue.

\section{Hypothesis $\mathbf{H 2}$}

Variable Capital expenditure has $\mathrm{t}$ value 0.508 and significance of $0.614>0.05$, it means that Capital expenditure partially does not have significant effect ob on Local independence financial . Public Accounting Standard Guide (PSAP) Number 2 stated that Capital expenditures is used for acquisition of fixed assets and other assets to provide benefits for more than one accounting period. Capital expenditures have specific characteristics that indicate various considerations in their allocation. Acquisition of fixed assets also has future consequences on operating and maintenance expenses (Bati, 2009).

This result is consistent with Lusiana (2013) that capital expenditure allocation has a positive but insignificant effect on level of financial independence of Regency / City Governments in Java Island. Kadafi, Dhanny, and Dewi Wahyuni (2018) has similar results that capital expenditure did not have a significant effect on local financial independence in all districts / cities of East Kalimantan Province. Adversely, Erlanda (2016) found that that capital expenditures and government capital participation have a positive and significant effect on local financial independence. 
Holtz-Eakin et al. in Rizky and Suryo (2009) showed a very close relationship between transfers from central government and capital expenditures. Prakoso's findings in Rizky and Suryo (2009) showed that capital expenditure is influenced by general allocation funds from central government. This provides a strong indication that behavior of local expenditures, especially capital expenditures, will be strongly influenced by this source of revenue.

\section{Hypothesis H3}

The significance value of sobel test showed a significance value of $0.000<0.05$. The $\mathrm{z}_{\text {count }}$ value of sobel test is $8.25<-1.96$. Therefore, it can be concluded that by using the $95 \%$ confidence level the General Allocation Fund has significant indirect effect on Local Financial Independence through Local revenue. .

Theoretically, the general allocation funds should balance the local financial capacities by improving people's purchasing power and increasing consumption and circulation of money in these regions. Higher consumption will affect the income of local taxes and levies. This will be better if local infrastructure expenditure prioritizes the development toe facilitate access between regions.

The local authority transfer was also followed by financing sources transfer from Central Government to local government. The regions can manage all their governmental affairs because the sources of financing have been transferred to local government. Realization of this mechanism can realize the aspirations of local independence realized. The financing sources transfer to regions will be manifested through a strong Local Revenue structure. This PAD is a financing source that is really extracted from region itself to reflect the real conditions of the region. Strong PAD structure indicates that the region has a strong financing capacity to realize local financial independence (Muliana, 2008).

\section{The Effect of Capital Expenditures on local financial independence mediated by local revenue}

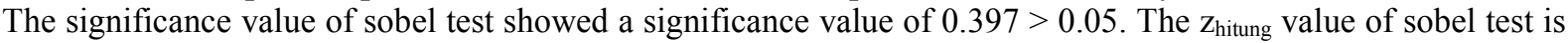
-0.26 so that $\mathrm{z}$ value is greater than -1.96 . Therefore, it can be concluded that Capital Expenditure has no significant indirect effect on Local Financial Independence mediated by Local revenue.

This is consistent Nugroho (2012) that capital expenditure has no effect on financial performance of local governments. However, capital expenditure has a significant positive effect on financial performance growth through local revenue.

This partial test supports the above analysis results that capital expenditure plays a role in local financial independence, it does not have a significant effect without support from by sufficient DAU allocations to increase people's purchasing power, and capital expenditure realization will not has a positive impact to increase local financial independence.

Prakoso in Rizky and Suryo (2009) found that capital expenditure is influenced by general allocation funds received from central government. Local independence will lower when central government transfers is larger. This provides a strong indication that behavior of local expenditures, especially capital expenditures, will be strongly influenced by the revenue source.

The local autonomy give regions the authority to explore financial sources to finance their own local expenditures. The financing from PAD should examine the effectiveness of local revenue, which is also supported by financial balancing funds between the central government and local equivalent to Province and Regency / City, which includes general allocation funds and special allocation funds. The local government should more effective to manage the local revenue (PAD) to increase the local revenue receipt. Large local revenue should reduce or even cover the amount of DAU from central government. If this can be achieved, region is said to be independent. This independence is shown by contribution of PAD to finance local expenditures.

\section{CONCLUSIONS AND SUGGESTIONS}

1. General Allocation Funds partially have a significant effect on local financial independence.

2. Capital Expenditures partially have a significant effect on level of local financial independence.

3. General Allocation Funds have a significant effect on local financial independence mediated by local revenue in districts / cities of North Maluku province.

4. The Capital Expenditures has a significant effect on local financial independence mediated by local revenue.

Based on above research results, following suggestions can be given.

1. Future researchers should analyze other factors to influence on factors that affect local financial independence with local revenue as an intervening variable .

2. This research can be used as a reference in developing other data analysis by adding other relevant independent variables.

3. The research should become input and contribution of thought for government of North Maluku province in making policies, and implementation in monitoring the distribution of financing so as to minimize the risk 
of financing that occurs.

(2008). Relevansi Transfer Pemerintah Pusat dengan Upaya Pajak Daerah Jurnal Kritis. Universitas Kristen Satya Wacana. Salatiga

(1981). "Fiscal Federalism in Canada 1981, Report of the Parliamentary Task Force on Federal-Provincial Fiscal Arrangements". Minister of Supply and Services, Canada.

Adi, Priyo Hari. (2006). Hubungan Antara Pertumbuhan Ekonomi Daerah, Belanja Pembangunan Dan Pendapatan Asli Daerah (Studi pada Kabupaten dan Kota se-Jawa-Bali). Simposium Nasional Akuntansi 9 Padang.

Ahmad, E. (1997). “Intergovernmental Transfers-An International Perspective". Bab 1 dalam "Financing Decentralized Expenditures: An International Comparison of Grants", editor Ehtisham Ahmad. Cheltenham, UK: Edward Elgar Publishing Ltd

Ariani, Kurnia Rini. (2010). Pengaruh Belanja Modal dan Dana Alokasi Umum Terhadap Tingkat Kemandirian Daerah dan Tax Effort Pemerintah Kabupaten/Kota Wilayah Eks Surakarta. Surakarta: Fakultas Ekonomi Universitas Sebelas Maret Surakarta.

BAPPENAS dan UNDP. (2008). Studi Evaluasi Dampak Pemekaran Daerah. Building and Reinventing Decentralised Governance.

Brodjonegoro, Bambang dan Jorge Martine-Vasque. (2002). An Analysis of Indonesia's Transfer System: Recent Performance and Future Prospect. George State University. Andrew Young School of Policy Studies. Working Paper.

Darwis. (2015). Pengaruh Belanja Modal dan Belanja Pegawai terhadap Tingkat Kemandirian Keuangan Daerah pada Kabupaten/Kota Provinsi Sumatera Barat. Fakultas Ekonomi Universitas Negeri Padang.

Erlanda, Safitri. (2016). Pengaruh Belanja Modal dan Penyertaan Modal Pemerintah terhadap Tingkat Kemandirian Daerah. Samarinda: Fakultas Ekonomi dan Bisnis Universitas Mulawarman.

Ghozali, Imam. (2005). Aplikasi Analisis Multivariat dengan program SPSS. Badan Penerbit Universitas Diponegoro. Semarang

Gujarati, Damodar N. (1995). Basic Econometrics. Third Edition. McGraw-Hill: New York.

Halim, Abdul. (2002), Akuntansi Sektor Publik: Akuntansi Keuangan Daerah, Salemba Empat, Jakarta.

Halim, Abdul. (2007). Bunga Rampai Manajemen Keuangan Daerah, Edisi Revisi, UPP AMP YPKN, Yogyakarta

Halim, Abdul. (2007). Akuntansi Sektor Publik: Akuntansi Keuangan Daerah. Jakarta: Salemba Empat.

Halim, Abdul, dan Muhammad Syam Kusufi. (2012). Akuntansi Sektor Publik: Akuntansi Keuangan Daerah. Jakarta: Salemba Empat.

Halim, Abdul, dan Muhammad Syam Kusufi. (2013). Akuntansi Keuangan Daerah. Jakarta: Salemba Empat.

Hari, Adi Priyo, (2006). Hubungan Antara Pertumbuhan Ekonomi Daerah, Belanja Pembangunan dan Pendapatan Asli Daerah, Simposium Nasional Akuntansi (SNA): Padang

Ismi Rizky dan Suryo. (2009). Pengaruh PAD dan Belanja Pembangunan terhadap Rasio Kemandirian dan Pertumbuhan Ekonomi. Konferensi Penelitian Keuangan Sektor Publik II.

Kadafi, Dhanny, dan Dewi Wahyuni. (2018). Pengaruh Belanja Modal dan Penyertaan Modal Pemerintah terhadap Tingkat Kemandirian Daerah pada Seluruh Kabupaten/Kota di Kalimantan Timur Tahun 20132017. Jurnal Eksis Vol 15 No 1 April 2019. Jurusan Akuntansi Politeknik Negeri Samarinda.

Kuncoro, Haryo. (2004). Pengaruh Transfer Antar Pemerintah Pada Kinerja Fiskal Pemerintah Daerah Kota dan Kabupaten di Indonesia. Jurnal Ekonomi Pembangunan Vol 9. No. 1, Juni 2004.

Lotz, J. R. (1997). "Denmark and Other Scandinavian Countries: Equalisation and Grants". Bab 7 dalam "Financing Decentralized Expenditures: An International Comparison of Grants", editor Ehtisham Ahmad. Cheltenham UK: Edward Elgar Publishing Ltd

Ma, Jun. (1997). "Intergovernmental Fiscal Transfer: A Comparison of Nine Countries (Cases of the United States, Canada, the United Kingdom, Australia, Germany, Japan, Korea, and India)". Makalah latar belakang teknis, Macroeconomic Management and Policy Division Economic Development Institute, The World Bank

Mahmudi, (2010). Manajemen Kinerja Sektor Publik, Yogyakarta: UPP. AMP. YPKN.

Mardiasmo. (2002). Otonomi dan Manajemen Keuangan Daerah. Penerbit ANDI. Yogyakarta

Mardiasmo. (2009). Akuntansi Sektor Publik. Yogyakarta: Andi Yogyakarta

Mathews, R. (1994). "Fiscal Equalisation-Political, Social and Economic Linchpin of Federation". Kuliah inagurasi Russell Mathews pada Hubungan Finansial Federal, Federalism Research Centre, Australian National University, Canberra.

Mihaljek, D. (1997). “Japan", Bagian II (12) dalam "Fiscal Federalism: in Theory and Practice”, editor Teresa Ter-Minassian. Washington: International Monetary Fund.

Muliana. (2009). Pengaruh Rasio Efektivitas PAD, DAU, dan DAK terhadap tingkat kemandirian keuangan daerah. Skripsi. Universitas Sumatera Utara. 
Musgrave, R. M. (1956). “The Theory of Public Finance”. New York: McGraw-Hill.

Niluh Putu Lindri, Puspitasari., Made Pradana Adiputra dan Niluh Gede Erni Sulindawati, (2016). Pengaruh Belanja Modal terhadap Pertumbuhan Kinerja Keuangan Daerah dengan Pendapatan Asli Daerah sebagai Variabel Intervening (Studi Kasus di Kabupaten Buleleng). Jurnal Akuntansi, Vol. 3, No. 1, Hal. 1-10

Republik, Indonesia. (2004). Undang-Undang Nomor 32 Tahun 2004 tentang Pemerintah Daerah

Republik, Indonesia. (2004). Undang-Undang Nomor 33 Tahun 2004 tentang Perimbangan antara Keuangan Pemerintah Pusat dan Pemerintah Daerah.

Rye, R. C. dan B. Searle. (1997). "Expenditure Needs: Institution and Data". Bab 3 dalam "Financing Decentralized Expenditures: An International Comparison of Grants", editor Ehtisham Ahmad. Cheltenham UK: Edward Elgar Publishing Ltd.

Rostow dan Musgrave, (1996). Pembangunan Ekonomi. Ekonomi Perencanaan Pembangunan, PT. Raja Grafindo Pustaka, Jakarta.

Saruc, Naci Tolga dan Isa Sagbas. (2008. The Surge Impact of the Flypaper, Substitution and Stimulation Effect on Local Tax effort in Turkey. International Research Journal of Finance and Economics. Euro Journals Publishing, Inc.

Schroeder, L. dan P. Smoke. (2003). “Intergovernmental Fiscal Transfers: Concepts, International Practice, and Policy Issues". Bab 2 dalam P. Smoke dan Y. H. Kim (Ed.) "Intergovernmental Transfers in Asia: Current Practice and Challenges for the Future”, hal. 20-59. Manila: Asian Development Bank.

Sivagnanam, K., Jothi dan M., Naganathan. 1999. Federal Transfer and The Tax Efforts of The States In India. Indian Economic Journal Vol 47, No. 4, 2000 (pp101-110).

Spahn, P. B. (1997). "Intergovernmental Transfers in Switzerland and Germany". Bab 5 dalam "Financing Decentralized Expenditures: An International Comparison of Grants", editor Ehtisham Ahmad. Cheltenham, UK: Edward Elgar Publishing Ltd,.

Sugiyono, S. 2012. Business Research Methods. Bandung: Alfabeta

Sularso, Havid, Restianto, yanuar . E, 2011. Pengaruh Kinerja Keuangan terhadap Alokasi Belanja Modal dan Pertumbuhan Ekonomi Kabupaten/Kota di Jawa Tengah, Media Riset Ekonomi, Purwokerto.

Syahputra, Adi. 2006. Perpajakan. USU Repository. Sumatera Utara

Walsh, C. dan N. Thomson. (1994). "Federal Fiscal Arrangements in Australia: Their Potential Impact on Urban Settlement". Federalism ResearchCentre, ANU, Canberra. 